\title{
SEARCH FOR THE LITTLE ICE AGE IN SOUTHERN OCEAN SEA-ICE RECORDS
}

\author{
by
}

\author{
Claire L. Parkinson
}

(Oceans and Ice Branch/Code 671, NASA Goddard Space Flight Center, Greenbelt, MD 20771, U.S.A.)

\section{ABSTRACT}

Records from the expeditions of Cook, Bellingshausen, Wilkes, and Ross in the late 18 th and early 19 th centuries have been examined for the information they provide on locations of the Southern Ocean sea-ice edge during the period of the late Little Ice Age in much of the Northern Hemisphere. When these locations are compared with satellite-derived ice edge locations in the mid 1970s, there is a suggestion of particularly heavy ice covers in the eastern Weddell Sea in December 1772, in the Amundsen Sea in March 1839, and perhaps, on the basis of an isolated observation, in a portion of the western Weddell Sea in January 1820. However, overall no strong Little Ice Age signal is found for the sea ice of the Southern Ocean. Many of the observations from the four expeditions indicate sea-ice edge locations that lie within the range of ice edge locations at the same time of year in the mid 1970s, and a few of the observations suggest a less extensive ice cover than in the 1970s.

\section{INTRODUCTION}

The Little Ice Age, generally regarded as centered somewhere in the 16th to mid-19th centuries, is well documented for many regions of the Northern Hemisphere, although with differing intensities and temporal extents at different locations (see Lamb, 1977; Grove, 1988; and the many references therein). The situation in the Southern Hemisphere is less definite. Although a few studies show Little Ice Age signals at specific locations in the Southern Hemisphere (e.g. Morgan (1985) for Law Dome, Antarctica, and Thompson and others (1986) for the Quelccaya Ice Cap, Peru), it remains uncertain whether the cooling period signified by the Little Ice Age was a global phenomenon. This paper addresses the issue of whether or not a Little Ice Age signal is present in the historic records of sea ice in the Southern Ocean.

Sea ice is such an integral component of the polar climatic regime, affecting and being affected by the atmosphere and oceans in numerous ways (Barry, 1983; Parkinson and others, 1987), that it is of ten suggested that sea ice should be a good index of climate (a suggestion which is by no means proved). Indeed, when the Northern Hemisphere Little Ice Age is discussed, sea-ice records are frequently mentioned, especially the record of ice along the coast of Iceland. The Iceland record, which is compiled and analyzed at length in Koch (1945) and brought up to date in Lamb (1977), is the longest historical sea-ice record and covers the entire Little Ice Age period plus preceding and succeeding centuries. Under certain frequently reproduced groupings of the Iceland data, a strong Little Ice Age signal appears (Koch, 1945; Lamb, 1977; Grove, 1988), and this signal is likely to hold up under scrutiny in spite of recent questions raised regarding the Iceland data (e.g. Ogilvie, 1984; Parkinson, 1989).

In contrast, Southern Hemisphere sea ice is rarely mentioned in discussions of the Little Ice Age, an understandable omission considering the lack of data.
Unfortunately there are no consistent long-term sea-ice records covering the full length of this period from any location in the Southern Hemisphere. In fact for the early Little Ice Age there are no direct written records of Southern Ocean sea ice at all. The records that exist for the later Little Ice Age consist of ship reports from random expeditions in the Southern Ocean, resulting in a database that is extremely sparse both spatially and temporally. Nonetheless, the latter records provide information that, in the effort to understand past climates, is worth examining in conjunction with 20th century conditions. A preliminary attempt in this direction is made in this paper by comparing Southern Ocean ice edge locations indicated in ship reports from several major expeditions in the late 18th and early 19th centuries with ice edge locations determined at the same times of year for 1973-76, the purpose being to examine whether or not a Little Ice Age signal is present.

The years 1973-76 were selected for comparison because (1) they fall well outside the Little Ice Age period, in a time by which global temperatures are estimated to have warmed considerably since the late 19th century (Jones and others, 1986; Hansen and Lebedeff, 1988), and (2) a consistent satellite-derived sea-ice data set for the Southern Ocean is available that includes data for most three-day periods throughout the four years 1973-76. The 1973-76 sea-ice record is derived from the radiometric data of the Nimbus 5 Electrically Scanning Microwave Radiometer (ESMR), launched in December 1972, and is available in digitized form from the National Snow and Ice Data Center (NSIDC), World Data Center A for Glaciology, in Boulder, Colorado. The data set is described and analyzed in Zwally and others (1983), where color-coded monthly averaged maps of sea-ice concentrations are presented for all months of 1973-76 except the seven months with insufficient data, namely March, April, May, and August of 1973 and June, July, and August of 1975 . The spatial resolution of the data is approximately $30 \mathrm{~km}$, and the sea-ice concentrations are estimated to be accurate to within $15 \%$.

SEA ICE DURING THE LITTLE ICE AGE AND COMPARISONS WITH 1973-76

Records from several of the major expeditions to the Southern Ocean prior to 1850 have been examined for information on the location of the sea-ice edge. The expeditions include those led by James Cook in 1772-75, Thaddeus Bellingshausen in 1819-21, Charles Wilkes in 1838-42, and James Clark Ross in 1839-43. The ice edge locations found in the first three of these expeditions are listed chronologically in Tables I-III, with indications of whether these ice edge locations suggest a more extensive, less extensive, or comparably extensive ice cover as occurred at the same longitude and same time of year during the period 1973-76. The comparative ice edges for 1973-76 are those revealed by Nimbus 5 ESMR data.

Cook expedition

In 1772-75, Captain James Cook led a British 
TABLE I. ICE EDGE LOCATIONS RECORDED BY COOK (1777)

Date

Location*

Ice compared

with $1973-76$

1772

$14 \mathrm{Dec}$

$18 \mathrm{Dec}$

$26 \mathrm{Dec}$

$54^{\circ} 50^{\prime} \mathrm{S} \quad 21^{\circ} 34^{\prime} \mathrm{E}$ (Weddell Sea)

$55^{\circ} 08^{\prime} \mathrm{S} 24^{\circ} 03^{\prime} \mathrm{E}$ (Weddell Sea)

$58^{\circ} 31^{\prime} \mathrm{S} \quad 27^{\circ} 37^{\prime} \mathrm{E}$ (Weddell Sea)

$31 \mathrm{Dec}$

$60^{\circ} 21^{\prime} \mathrm{S} \quad 13^{\circ} 13^{\prime} \mathrm{E}$ (Weddell Sea)

1773

17 Jan

$15 \mathrm{Dec}$

23 Dec

$26 \mathrm{Dec}$

$67^{\circ} 15^{\prime} \mathrm{S} \quad 39^{\circ} 35^{\prime} \mathrm{E}$ (Indian Ocean)

$66^{\circ} 00^{\prime} \mathrm{S} 159^{\circ} 20^{\prime} \mathrm{W}$ (Ross Sea)

$67^{\circ} 20^{\prime} \mathrm{S} 137^{\circ} 12^{\prime} \mathrm{W}$ (Ross Sea)

$66^{\circ} 15^{\prime} \mathrm{S} 134^{\circ} 22^{\prime} \mathrm{W}$ (Ross Sea)

\begin{abstract}
more
more

more

more
\end{abstract}

within range

within range

less

less
1774

30 Jan

$71^{\circ} 10^{\prime} \mathrm{S} 106^{\circ} 54^{\prime} \mathrm{W}$ (Amundsen Sea) within range

* The Weddell Sea here and in Tables II and III is considered to extend from $60^{\circ} \mathrm{W}$ to $30^{\circ} \mathrm{E}$, in order to encompass the area of the 1974-76 Weddell polynya and Weddell ice tongue. The Indian Ocean is considered to extend from $30^{\circ} \mathrm{E}$ to $90^{\circ} \mathrm{E}$, the Pacific Ocean from $90^{\circ} \mathrm{E}$ to $160^{\circ} \mathrm{E}$, the Ross Sea from $160^{\circ} \mathrm{E}$ to $130^{\circ} \mathrm{W}$, the Amundsen Sea from $130^{\circ} \mathrm{W}$ to $95^{\circ} \mathrm{W}$, and the Bellingshausen Sea from $95^{\circ} \mathrm{W}$ to $60^{\circ} \mathrm{W}$.

expedition to discover the hypothesized Great Southern Continent in the high latitudes of the Southern Hemisphere. This was the first major expedition to remain in the Southern Ocean for an extended period and the first to cross the Antarctic Circle. Although many earlier expeditions had encountered outlying icebergs, few had reached the main ice pack and those had all been hindered in recording ice edge locations by the difficulties prior to the $1760 \mathrm{~s}$ of obtaining longitudes accurately from sea. During the 1772-75 expedition, Cook spent much of each austral summer poleward of $50^{\circ} \mathrm{S}$, circumnavigated the undiscovered Antarctic continent, and recorded the position of the ice edge at several locations, obtaining longitudes with the help of the newly-devised seaworthy chronometer of John Harrison (Cook, 1777).

When Cook's ice edge locations (Table I) are compared with ice edge locations during the ESMR period 1973-76, his December 1772 observations from the eastern Weddell Sea stand out as particularly noteworthy. These observations suggest a significantly heavier ice cover than occurred at the same time of year in the 1973-76 period. This is true especially of his 14-18 December observations in the vicinity of $55^{\circ} \mathrm{S}$, which are $2-8^{\circ}$ farther north than the mid-December ice edge at the same longitudes in 1973-76. On the other hand, it is clear from Cook's notes for the succeeding days, as he traveled southward in the absence of ice, that the ice encountered on 14-18 December was probably either an isolated field of ice or part of a tongue of ice lying well north of the rest of the ice at the same longitude. The possibility of an ice tongue is heightened by the fact that Cook's 31 December 1772 observation at $60^{\circ} 21^{\prime} \mathrm{S}, 13^{\circ} 13^{\prime} \mathrm{E}$ is of a sea-ice edge to his north, not his south. These observations suggest the spring/summer Weddell Sea ice tongue frequently found in satellite data (e.g. Zwally and others, 1983), although the timing and placement of the observations suggest a lag in the melt season of up to several weeks behind the timing for the 1970s. It should be noted that Cook's 26 December 1772 observation at $58^{\circ} 31^{\prime} \mathrm{S}, 27^{\circ} 37^{\prime} \mathrm{E}$ is of ice bands, not a solid ice pack.

Cook's observations around the remainder of the continent do not confirm the heavy ice cover (relative to that in the 1970s) found by him in the eastern Weddell Sea. His observations in the Ross Sea suggest slightly less ice than in the 1970s, and his observations in the Amundsen Sea at $71^{\circ} 10^{\prime} \mathrm{S}, 106^{\circ} 54^{\prime} \mathrm{W}$ and off the Kronprins Olav Kyst at $67^{\circ} 15^{\prime} \mathrm{S}, 39^{\circ} 35^{\prime} \mathrm{E}$ suggest ice edge locations within the range of interannual variability found from the ESMR data. The Weddell Sea/Ross Sea contrast is of interest, but so far remains unexplained. TABLE II. ICE EDGE LOCATIONS RECORDED BY
BELLINGSHAUSEN (1831)

Date

Location

Ice compared with 1973-76
1820

14 Jan

16 Jan

16 Jan

21 Jan

28 Jan

2 Feb

18 Feb

19 Feb

$11 \mathrm{Dec}$

$12 \mathrm{Dec}$

$13 \mathrm{Dec}$

$22 \mathrm{Dec}$

$23 \mathrm{Dec}$

$25 \mathrm{Dec}$

26 Dec

$31 \mathrm{Dec}$

1821

$10 \mathrm{Jan}$

12 Jan

25 Jan $59^{\circ} 13^{\prime} \mathrm{S} \quad 26^{\circ} 13^{\prime} \mathrm{W}$ (Weddell Sea) $60^{\circ} 25^{\prime} \mathrm{S} 27^{\circ} 38^{\prime} \mathrm{W}$ (Weddell Sea) within range $59^{\circ} 36^{\prime} \mathrm{S} 15^{\circ} 02^{\prime} \mathrm{W}$ (Weddell Sea) more $69^{\circ} 22^{\prime} \mathrm{S} \quad 2^{\circ} 15^{\prime} \mathrm{W}$ (Weddell Sea) within range $69^{\circ} 25^{\prime} \mathrm{S} \quad 1^{\circ} 11^{\prime} \mathrm{W}$ (Weddell Sea) within range $69^{\circ} 06^{\prime} \mathrm{S} \quad 15^{\circ} 16^{\prime} \mathrm{E}$ (Weddell Sea) less $68^{\circ} 05^{\prime} \mathrm{S} 16^{\circ} 37^{\prime} \mathrm{E}$ (Weddell Sea) within range $63^{\circ} 17^{\prime} \mathrm{S} 166^{\circ} 58^{\prime} \mathrm{E}$ (Ross Sea) $64^{\circ} 55^{\prime} \mathrm{S} 170^{\circ} 10^{\prime} \mathrm{E}$ (Ross Sea) $64^{\circ} 19^{\prime} \mathrm{S} 173^{\circ} 41^{\prime} \mathrm{E}$ (Ross Sea) $65^{\circ} 41^{\prime} \mathrm{S} 172^{\circ} 01^{\prime} \mathrm{W}$ (Ross Sea) $65^{\circ} 54^{\prime} \mathrm{S} 170^{\circ} 22^{\prime} \mathrm{W}$ (Ross Sea) $66^{\circ} 30^{\prime} \mathrm{S} 164^{\circ} 34^{\prime} \mathrm{W}$ (Ross Sea) $67^{\circ} 16^{\prime} \mathrm{S} 161^{\circ} 28^{\prime} \mathrm{W}$ (Ross Sea) $64^{\circ} 21^{\prime} \mathrm{S} 155^{\circ} 21^{\prime} \mathrm{W}$ (Ross Sea)

$$
\text { more }
$$

within range more

within range within range within range within range within range $65^{\circ} 43^{\prime} \mathrm{S} 126^{\circ} 30^{\prime} \mathrm{W}$ (Amundsen Sea) more $67^{\circ} 30^{\prime} \mathrm{S} 119^{\circ} 48^{\prime} \mathrm{W}$ (Amundsen Sea) within range $69^{\circ} 08^{\prime} \mathrm{S} 76^{\circ} 52^{\prime} \mathrm{W}$ (Bellingshausen Sea) within range

\section{Bellingshausen expedition}

In 1819-21, Captain Thaddeus Bellingshausen led a Russian expedition to explore the south polar waters. Bellingshausen circumnavigated the Antarctic continent, remaining south of $60^{\circ} \mathrm{S}$ for over half the distance and traveling along the ice edge for several stretches during January-February 1820 and December 1820-January 1821 . He spent the intervening winter period in the South Pacific (Bellingshausen, 1831), as had Cook (1777) during his voyages. Bellingshausen's discoveries west of the Antarctic Peninsula led to the naming of the Bellingshausen Sea.

Comparison of Bellingshausen's ice edge locations (Table II) with the ESMR satellite record reveals most of Bellingshausen's observations to fall within the range of ice edge locations found in 1973-76. A prominent exception occurs on 21 January 1820, when Bellingshausen records sea ice at $59^{\circ} 36^{\prime} \mathrm{S}, 15^{\circ} 02^{\prime} \mathrm{W}$. This is far north (almost $10^{\circ}$ of latitude) of the position of the ice edge in late January in the 1970s; and yet Bellingshausen's description of an ice field extending "from northeast to southsouthwest, in the midst of which were wedged a large number of large flat icebergs" (Bellingshausen, 1831) definitely suggests the presence of sea ice, not just icebergs and iceberg debris. Further, the consistency of his recorded locations on preceding and succeeding days eliminates the likelihood of a major error in recording latitude. It is conceivable that Bellingshausen encountered a small ice field well distant from the main ice pack. Otherwise it appears that at this longitude the ice cover in January 1820 was much heavier than that in January 1973-76.

The four other ice edge locations listed in Table II as falling outside the 1973-76 range were all outside that range by less than $1^{\circ}$ of latitude. This includes the 18 February 1820 Weddell Sea observation of less ice than in 1973-76, the two December 1820 Ross Sea observations of more ice than in 1973-76, and the 10 January 1821 Amundsen Sea observation of more ice than in 1973-76. The low ice cover indicated in the Weddell Sea on 18 February 1820 and the 28 January 1820 and 2 February 1820 ice edge locations (which fall within the 1973-76 range) support the conjecture that the observation of ice at a particularly low latitude on 21 January 1820 either was of a separated field of ice distant from the main ice pack, or signified an unusually late retreat of the Weddell Sea ice tongue. A reviewer pointed out the possibility that the heavy ice cover on 21 January, although an isolated observation, could be related to the widespread cooling following the 1815 eruption of Tambora. It would be interesting to examine such a connection with data from the 
TABLE III. ICE EDGE LOCATIONS RECORDED DURING THE WILKES EXPEDITION (FROM BERTRAND, 1971)

Date

Location

Ice compared with 1973-76

1839

$20 \mathrm{Mar}$

$21 \mathrm{Mar}$

$24 \mathrm{Mar}$ $67^{\circ} 30^{\prime} \mathrm{S} 105^{\circ} 00^{\prime} \mathrm{W}$ (Amundsen Sea) $68^{\circ} 41^{\prime} \mathrm{S} 103^{\circ} 34^{\prime} \mathrm{W}$ (Amundsen Sea) $69^{\circ} 06^{\prime} \mathrm{S} 96^{\circ} 50^{\prime} \mathrm{W}$ (Amundsen Sea)

more more more

\section{0}

11 Jan

13 Jan

15 Jan

19 Jan

23 Jan

23 Jan

24 Jan

$2 \mathrm{Feb}$

$8 \mathrm{Feb}$

17 Feb

$20 \mathrm{Feb}$

$24 \mathrm{Feb}$

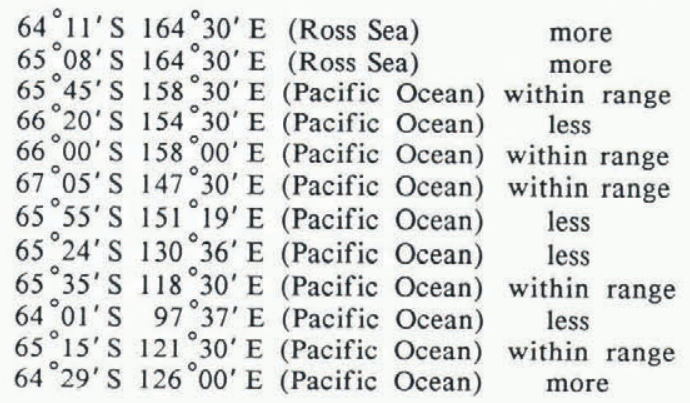

years prior to and immediately following the eruption.

\section{Wilkes expedition}

The United States Exploring Expedition of 1838-42, led by Lieutenant Charles Wilkes, was a four-year, wideranging expedition of exploration in many regions of the world's oceans, with exploratory parties sent inland at numerous coastal locations. The expedition included two major excursions into Southern Ocean waters, the first in February and March of 1839 and the second in January and February of 1840. During the latter period, Wilkes and his subordinates journeyed for 1500 miles along the edge of the pack ice south of Australia, off what has become known as Wilkes Land (Bertrand, 1971). The ice edge locations listed in Table III are from several ships taking part in the Wilkes expedition.

Wilkes found a heavier ice cover in the Amundsen Sea in March 1839 than existed in March of 1974-76 (March 1973 data are not available), with the three Amundsen Sea ice edge locations listed in Table III falling outside the latitude range of the 1974-76 ice edges at the respective longitudes by $1-2.5^{\circ}$ of latitude. The two Ross Sea locations listed in Table III, for mid-January 1840, also suggest a heavier ice cover than at the same time of year in $1973-76$, in this case by $1-1.5^{\circ}$ of latitude. However, as the Wilkes expedition traveled westward from the Ross Sea, their ice edge locations tended to be within the 1973-76 range or slightly poleward (by less than $1^{\circ}$ of latitude) of the 1973-76 range. The one exception to this in Table III, the final entry, concerns an ice edge location equatorward of the 1973-76 range by less than $0.5^{\circ}$ of latitude.

[It should be noted that the source used for Wilkes (Bertrand, 1971), in contrast to those used for Cook, Bellingshausen, and Ross, is a secondary source, not the direct records of Wilkes or of anyone in his expedition. Many more ice edge locations are likely to be found by examining the various primary sources from Wilkes and his colleagues.]

\section{Ross expedition}

The 1839-43 expedition led by Sir James Clark Ross was a British scientific expedition to measure magnetic direction and intensity in high southern latitudes and to attempt to reach the South Magnetic Pole. As a part of the latter effort, Ross sailed through the later-named Ross Sea and explored along the adjacent Antarctic coastline and Ross Ice Shelf in January, February, and March of 1841 (Ross, 1847). Although Ross returned to the Ross Sea the following summer and then attempted to penetrate the sea ice of the Weddell Sea in 1843, it is his Ross Sea exploration of 1841 which is discussed here. Because of sailing through rather than along the ice pack, Ross's mentions of outer ice edge locations during the Ross Sea portion of his voyage are fewer than those of Bellingshausen or Wilkes. However, Ross gives more information on local sea-ice conditions and the existence or non-existence of open water areas within the ice pack.

Ross encountered the ice edge late in the morning on 1 January 1841 , and was just within the ice pack at noon, when his location was $66^{\circ} 32^{\prime} \mathrm{S}, 169^{\circ} 45^{\prime} \mathrm{E}$. This is within the 1973-76 range of outer ice edge locations on 1 January at that longitude. Similarly, Ross was somewhat within the pack on 5 and 6 January when at $66^{\circ} 55^{\prime} \mathrm{S}, 174^{\circ} 34^{\prime} \mathrm{E}$ and $68^{\circ} 17^{\prime} \mathrm{S}, 175^{\circ} 21^{\prime} \mathrm{E}$, respectively, and both these locations are within the 1973-76 range of ice distributions for 5 and 6 January. Ross, still traveling southward, reached open water early on 9 January 1841, continuing in open water at noon, when his location was $69^{\circ} 15^{\prime} \mathrm{S}, 176^{\circ} 15^{\prime} \mathrm{E}$. This location was also open on 9 January in both 1974 and 1975 , in the former case as part of an embayment reaching southward to the Ross Ice Shelf and in the latter case as part of a large Ross Sea polynya. In 1973 there was ice in this location but only as part of a band separating a large Ross Sea polynya to the south from the open water to the north. As Ross explored the southern Ross Sea for the remainder of January and February 1841, his several indications of where he encountered ice and where he encountered open water are all consistent with 1973-76 conditions, generally indicating more ice than in 1975 but less ice than in 1976.

In March 1841 Ross traveled along the ice edge off Victoria Land, proceeding westward from $167^{\circ} \mathrm{E}$ to $142^{\circ} \mathrm{E}$. $\mathrm{His}$ recorded ice edge locations along this route, between $68^{\circ}$ and $65^{\circ} \mathrm{S}$ from $167^{\circ} \mathrm{E}$ to $162^{\circ} \mathrm{E}$ and between $63^{\circ}$ and $65.2^{\circ} \mathrm{S}$ from $162^{\circ} \mathrm{E}$ to $142^{\circ} \mathrm{E}$, predominantly fall within the range of ice edge locations for March 1974-76. Hence the sea-ice locations found by Ross in the Ross Sea vicinity during the first three months of 1841 suggest ice distributions similar to those in the 1970s.

\section{Sealers and whalers}

Many sealers and whalers in the late 18th and entire 19 th centuries spent considerable time in Southern Ocean waters, and some made important exploratory voyages, partly in search of better sealing grounds. Among these were the Englishman James Weddell, who in 1822 sailed as far south as $74^{\circ} 15^{\prime} \mathrm{S}$ in the later-named Weddell Sea, and the American Nathaniel B. Palmer, who explored along the Antarctic Peninsula in the 1820 s and 1830 s, leading to the naming of Palmer Land. The logbooks of many of the sealing expeditions are available (some sources are given in Bertrand, 1971), and a careful study of them could perhaps yield valuable information for climate studies. However, there are difficulties with many of these records, and for two reasons in particular they are not included in this study. The first reason lies in the frequent failure of many whalers and sealers to record accurate locations. This failure was often quite deliberate, the purpose being to hinder competitors from relocating select whaling or sealing grounds (Bertrand, 1971). The second reason relates to a failure not of the whalers and sealers but of the satellite data being used for comparisons. Many of the whaling and sealing expeditions concentrated efforts amongst the islands of the Antarctic Peninsula or elsewhere in the near vicinity of land. The $30 \mathrm{~km}$ resolution of the satellite data makes it inappropriate for detailed studies in near-shore regions, where land contamination confounds the interpretation of the satellite data.

\section{Summary}

The ice edge locations mentioned in the various expedition reports discussed here do not indicate a strong Little Ice Age signal when compared with the ice edge locations found at the same times of year in the four-year period in the 1970 s having satellite data coverage from the Nimbus 5 ESMR. In December 1772 Cook found a more extensive ice cover in the eastern Weddell Sea than appeared in December 1973-76, but a year later he found a somewhat less extensive ice cover in the Ross Sea than existed in December 1973-76. One of the ice edge locations given by Bellingshausen is well outside the 1973-76 range, suggesting a particularly extensive Weddell Sea ice cover on 21 January 1820 , but that was an isolated instance preceded and succeeded by several Weddell Sea observations of ice 
edge locations within the 1973-76 range. Wilkes's Amundsen Sea ice edge locations in March 1839 and Ross Sea ice edge locations in January 1840 suggest a somewhat more extensive ice cover than in March 1974-76 and January 1973-76 respectively, and these might be usable in supporting an hypothesis of a weak Little Ice Age signal, especially if bolstered by additional data. However, neither Wilkes's observations along the Wilkes coast in 1840 nor Ross's observations in the Ross Sea and off Victoria Land in 1841 suggest more extensive ice conditions than in the 1970s. Hence, although a few observations from these expeditions suggest more extensive ice coverage than in the ESMR years 1973-76 (and a few observations suggest less extensive coverage), there is no clear-cut evidence of significantly more extensive ice overall. The evidence instead suggests ice conditions generally not far different from those in the 1970s.

\section{DISCUSSION}

Many problems exist in trying to establish sea-ice conditions from historical records during the Little Ice Age period. Most crucial is the lack of data. No well-documented precise ice edge locations are known to exist prior to the records of James Cook from the 1770s. After the 1770s, sealers and whalers were among the most frequent visitors to the Southern Ocean, but they often deliberately kept their locations secret (Bertrand, 1971). Explorers, on the other hand, frequently took great care to obtain accurate latitudes and longitudes, but to maximize their chances of making significant discoveries (and surviving), they purposely did their Southern Ocean explorations in summertime. As a result, almost all records prior to the late 19th century are from the summer season. Furthermore, in no case during the Little Ice Age period was the determination of sea-ice conditions a primary purpose of a voyage, and hence the written records revealing information on sea-ice distributions tend to be secondary notes in journals stressing other topics. Consequently, latitudes and longitudes are of ten not provided for the points at which the sea-ice edge was encountered, and in some instances when ice is mentioned it is not made clear whether the ice referred to is sea ice, icebergs, or iceberg debris. All these factors limit the amount of explicit information on sea-ice distributions that can be determined from ship records in the 18th and 19th centuries. Nonetheless, useful information is obtainable and an attempt has been made to examine some of it from the historic records of Cook, Bellingshausen, Wilkes, and Ross.

This is a preliminary study, concerned only with ice edge locations and with the records of a limited but important sampling of expeditions to the Southern Ocean region. A thorough examination of all records from the period of the Little Ice Age would yield both more ice edge positions and also considerably more information on sea-ice conditions at specific times and places. This would be tedious, although could well be profitable in indicating more about changes in sea-ice conditions over the past few centuries, especially if the study were to include the full period from the first sea-ice records to the present time. The known high interannual variability of the sea-ice cover, for example for the four Nimbus 5 ESMR years analyzed by Zwally and others (1983), underscores the desirability of as complete a data record as possible. However, the evidence from this preliminary study suggests that it is unlikely that a thorough study will yield a strong and consistent Little Ice Age signal from the sea ice of the Southern Ocean, at least for the 1770-1850 period.

Possible explanations for why the Southern Ocean sea ice might not indicate a Little Ice Age signal for 1770-1850 include: (1) the Little Ice Age might not have been global, and specifically might not have occurred in the region of the Southern Ocean; (2) the Little Ice Age might have occurred in the Southern Ocean, but centered either prior to or subsequent to the $1770-1850$ period; (3) the Southern Ocean sea ice might not be a good indicator of the climate state, at least during this $1770-1850$ time period. The data presented here are insufficient for selecting among these alternatives. Morgan (1985) concludes from analysis of ice cores that at Law Dome, Antarctica $\left(66^{\circ} 44^{\prime} \mathrm{S}, 112^{\circ} 50^{\prime} \mathrm{E}\right)$ the coldest period over the last 2000 years occurred between 1790 and 1850 . However, similar data would be needed from many more locations in order to eliminate alternatives (1) and (2), especially considering the high spatial variability known to exist in temperature distributions and trends for the Antarctic region (van Loon and Williams, 1977; Swanson and Trenberth, 1981; Raper and others, 1984). Should additional temperature data eventually confirm a peaking of the Little Ice Age in the late 18th and early 19th centuries in the Southern Ocean region, then the lack of a strong signal in the sea-ice data would put a damper on speculations that sea ice might be a good indicator of climate. In the meantime, many uncertainties remain, compounded by (a) the high spatial and interannual variability in the temperatures and sea ice known from the records of the past few decades and (b) the very sporadic nature of the historical temperature and sea-ice records from the Southern Ocean region. In view of the sparsity of historically recorded data, the most likely sources for untangling the uncertainties could well be the proxy climate indicators found in ice cores and deep-sea cores from the Antarctic continent and the sediments underlying the Southern Ocean.

\section{ACKNOWLEDGEMENTS}

This work was funded by the Oceanic Processes Branch at NASA Headquarters, whose support is greatly appreciated. Many thanks also go to Peter Wadhams and the rest of the Scott Polar Research Institute for allowing and helping me to examine the records in their impressive polar library, and to Doug MacAyeal and two anonymous reviewers for their comments on the manuscript.

\section{REFERENCES}

Barry, R.G. 1983. Arctic Ocean ice and climate: perspectives on a century of polar research. Ann. Assoc. Amer. Geogr., 73(4), 485-501.

Bellingshausen, T. 1831. The voyage of Captain Bellingshausen to the Antarctic seas 1819-1821. London, Hakluyt Society. [1945 translation.]

Bertrand, K.J. 1971. Americans in Antarctica 1775-1948. New York, American Geographical Society.

Cook, J. 1777. A voyage towards the South Pole, and round the world. Performed in His Majesty's ships the "Resolution" and "Adventure" in the years 1772, 1773. 1774, and 1775. London, W. Strahan and T. Cadell.

Grove, J.M. 1988. The Little Ice Age. London and New York, Methuen.

Hansen, J. and S. Lebedeff. 1988. Global surface air temperatures: update through 1987. Geophys. Res. Lett., 15(4), 323-326.

Jones, P.D., T.M.L. Wigley, and P.B. Wright. 1986. Global temperature variations between 1861 and 1984. Nature, 322(6078), 430-434.

Koch, L. 1945. The East Greenland ice. Medd. Gronl., 130(3), 1-374.

Lamb, H.H. 1977. Climate: present, past and future. Vol. 2. Climatic history and the future. London and New York, Methuen.

Morgan, V.I. 1985. An oxygen isotope-climate record from the Law Dome, Antarctica. Climatic Change, 7(4), 415-426.

Ogilvie, A.E.J. 1984. The past climate and sea-ice record from Iceland. Part I. Data to A.D. 1780. Climatic Change, 6(2), 131-152.

Parkinson, C.L. 1989. Dangers of multiyear averaging in analyses of long-term climate trends. Climate Dynamics, 4(1), 39-44.

Parkinson, C.L., J.C. Comiso, H.J. Zwally, D.J. Cavalieri, P Gloersen, and W.J. Campbell. 1987. Arctic sea ice, 1973-1976: satellite passive-microwave observations. Washington, DC, National Aeronautics and Space Administration. (NASA SP-489.)

Raper, S.C.B., T.M.L. Wigley, P.R. Mayes, P.D. Jones, and M.J. Salinger. 1984. Variations in surface air temperatures. Part 3. The Antarctic, 1957-82. Mon. Weather Rev., 112(7), 1341-1353.

Ross, J.C. 1847. A voyage of discovery and research in the 
southern and Antarctic regions, during the years 1839-43. London, John Murray.

Swanson, G.S. and K.E. Trenberth. 1981. Trends in the Southern Hemisphere tropospheric circulation. Mon. Weather Rev., 109(9), 1879-1889.

Thompson, L.G., E. Mosley-Thompson, W. Dansgaard, and P.M. Grootes. 1986. The Little Ice Age as recorded in the stratigraphy of the tropical Quelccaya ice cap. Science, 234(4774), 361-364.

Van Loon, H. and J. Williams. 1977. The connection between trends of mean temperature and circulation at the surface. Part IV. Comparison of the surface changes in the Northern Hemisphere with the upper air and with the Antarctic in winter. Mon. Weather Rev., 105(5), 636-647.

Zwally, H.J., J.C. Comiso, C.L. Parkinson, W.J. Campbell, F.D. Carsey, and P. Gloersen. 1983. Antarctic sea ice, 1973-1976: satellite passive-microwave observations, Washington, DC, National Aeronautics and Space Administration. (NASA SP-459.) 